\title{
e-Migrinter
}

$18 \mid 2019$

L'ethnographie en migration(s)

\section{A multi-sited ethnography on cultural scenes and international migration}

Reflecting on sites, links and para-ethnographers

Magali N. Alloatti

\section{OpenEdition}

\section{Journals}

Electronic version

URL: https://journals.openedition.org/e-migrinter/1652

DOI: 10.4000/e-migrinter. 1652

ISSN: 1961-9685

\section{Publisher}

UMR 7301 - Migrinter

\section{Electronic reference}

Magali N. Alloatti, "A multi-sited ethnography on cultural scenes and international migration", e-

Migrinter [Online], 18 | 2019, Online since 12 September 2019, connection on 20 May 2021. URL: http:// journals.openedition.org/e-migrinter/1652 ; DOI: https://doi.org/10.4000/e-migrinter.1652

This text was automatically generated on 20 May 2021.

Tous droits réservés 


\title{
A multi-sited ethnography on cultural scenes and international migration
}

Reflecting on sites, links and para-ethnographers

\author{
Magali N. Alloatti
}

\section{AUTHOR'S NOTE}

A short version of this work was presented at the doctoral students' day at the conference « Thinking Migration to Rethink the World ». University of Poitiers, MIGRINTER, 21-24 June 2016. France.

\section{Introduction}

1 On September 27, 2015, I was scheduled to participate in a parade with a group of women who learn and practice Afro-Brazilian dances in Los Angeles. This event was part of the Abbot Kinney Festival, an annual celebration with games, cultural activities and music shows to collect money for social projects and the betterment of the neighborhood. Abbot Kinney street is connected to Venice Boulevard, one of the most important thoroughfares in West Los Angeles, and is around ten minutes from Venice Beach. I had previously met the group's teacher, a 65-year-old American woman, whom I call Nina ${ }^{1}$, with a long trajectory in the field of Afro-Brazilian dance and arts. She teaches what are frequently called Orixá dances, which honor the divinities (Orixás) of the Candomblé religion.

2 Candomblé-the Brazilian religion of Orixás and other African divinities, constituted in the state of Bahia during the 19th century-together with other religious practices [...] is considered an institution of cultural resistance, first by Africans, and then by Afrodescendants. It is resistance to slavery and mechanisms of domination of white and 
Christian society, which marginalized black and mestiço populations even after the abolition of slavery. These religions seek to preserve ethnic heritage and are based in small groups that gather (and are organized) around a mãe de santo (priestess) or pai de santo (priest). (Prandi, 2004: 223 and 229. Original text in Portuguese ${ }^{2}$ ).

According to Nina and Sarah, both prominent teachers and references on AfroBrazilian dance in Los Angeles, there are regularly taught movements and dances that are similar to those performed during rituals and celebrations in Brazil. Yet in the case of Los Angeles, Orixá dance is offered in a similar fashion to other dances (such as samba): in weekly lessons at dance studios that are always open to newcomers. In the occasion of the Abbot Kinney parade, Nina recommended (through the Facebook group) that I participate first in an earlier lesson to get ready for the parade, which was scheduled for noon. As this would be the first time that I would be dancing with this group and observing a parade of Orixá dance in an open public space, I took her advice. During the lesson, I learned that the parade was not only part of the festival, but also an energetic cleansing ritual which would wash away the bad energy and sadness in the neighborhood caused by the process of gentrification. At that moment, I realized that the event, as something that happens in a particular time and space, was actually several things at the same time. Or rather, the event had different layers of meaning depending on one's degree of access, as determined by their knowledge of Orixá dance and their membership to the group. I only knew that the parade was a ritual because Nina told us during the class. I learned that this ritual was sacred and possible because a mãe de santo (a Candomblé priestess) would be part of it, dancing with the group. The mãe de santo had arrived in Los Angeles the day before, having been invited to teach, give cultural advice and design the costumes for other occasions.

This experience made me reflect on how superficial and limited my observing, participating and registering of Brazilian cultural events really were. Consequently, what hope did I have to understand and explain what I observed and the cultural and symbolic dynamics embedded in those situations? I felt this question was closely related to criticism about the conventions of traditional ethnography, specifically that "experience underlies the comprehension of all social life" (Van Maanen, 2011, p. 3). This implies that through a shared experience between the observer and the observed, by "being there," the authority of the ethnographer is shown, and, simultaneously, proved. It was evident that I had limited access to the meanings that were created and circulated in the events I was observing, a limitation which directly impacted my comprehension of the subject's practices and discourses. Furthermore, it made me question the social space as a site and the observation as an epistemological device, in addition to the proof of presence and the (necessary?) depth of my ethnographic work. These concerns prompted me to seek other courses of action regarding ethnography, and I partially solved these problems by incorporating a multi-sited approach.

5 Marcus proposed the emergence of multi-sited ethnography in his 1995 article addressing methodological and epistemological debates and anxieties due to new phenomena in the dislocation of a conventional single site study (dwelling) to multiple sites (local, global) necessary for then-current times. By doing so, Marcus problematizes the explanatory power of fieldwork as traditionally conducted and its implications regarding the researcher, subjects and limits of comprehension. Marcus introduces the idea of "tracking" as "following" the people, things or metaphors. He bases this idea on contributions by Appadurai (1986) and Clifford (1997) regarding the 
circulation of things, meanings and practices that prompted new knowledge-making processes. At the same time, he offers elements to the debate around the imagined construction of spaces and the "attachment" of culture (Gupta and Ferguson, 1997; 2001). Marcus's contribution, although polished and improved through time (Collerman and Hellerman, 2011), has been questioned with respect to what it actually means to conduct fieldwork in a multi-sited fashion, in and through a multiplicity of sites (Hannerz, 2003; Hage, 2005). However, Marcus's work has inspired generous discussion and further developments, mostly focused on international migration (Amelina, 2010; Boccagni, 2010; 2014) and social dynamics that boost connections between sites and locales (Gallo, 2009; Brickell and Datta, 2011). Of considerable importance are the books organized by Falzon (2009) and Collerman and Hellerman (2011), which offered multiple empirical examples of multi-sited ethnographies, including its limitations, advances and obstacles.

6 As a product of the above-mentioned literature and my own process of questioning and reflection, this article discusses some of the challenges I faced while conducting my research in Los Angeles (in 2015 and part of 2016) regarding methodological choices and their consequences. I start by defining my unit of research: cultural scenes in which Brazilian culture is performed and connected to ethnic identities as forms of narratives. Various difficulties of a practical nature emerged during the research, as did theoretical and methodological complications. I discuss two of these complications: my conceptualization of space and sites and my relationship with the subjects who participated in my research. To this end, I articulate three main elements present in the current debate around multi-sited perspectives.

7 First, I utilize the definition of para-ethnographers (Holmes and Marcus, 2005; Marcus, 2011) to characterize some of the people I interviewed and with whom I developed this research. This notion helped me qualify their agency, social positions and narratives. Therefore, I understand them as knowledge-makers who create and maintain information about the dynamics of the specific field in which they are inserted. Second, by defining cultural scenes as my unit of analysis, I singularize their existence in a specific junction of time and space (Gallo, 2009) and as configurations of the performances and social disputes around Brazilian culture. Third, connected to the latter, I retrieve the discussion around sites. Deconstructing the bounding between places and culture (Gupta and Ferguson, 1997; 2001) allows one to identify how geographical references are imagined, (re)created and intertwined by transnational and local ties, interactions and circulations of meanings, goods and people. By reflecting on the ties among spaces and cultural scenes, I analyze how some individuals were, in fact, bridges that connected sites through different modalities. In the conclusion, I summarize how this experience elicited the challenge of adapting methodologies and frameworks that were guided by the constant reflection of the fieldwork process. 


\section{Researching ethnic identities and cultural performances: conceiving a multi-sited research project}

\section{The site as the unit of analysis, but what constitutes a site?}

8 I based my project on recent research on the importance of Brazilian culture in the context of migration. I used a restricted sense of culture, with a focus on performances of dance, music, arts or religion that are defined and advertised by exclusive cultural content attached to Brazil. According to Frangella (2013), it is possible to understand these events as cultural scenes, as social spaces organized in a hierarchy of importance in terms of symbolic and social capital. Following the work of Ribeiro (1999) in San Francisco and Coimbra de Sá (2011) in New York, I planned to observe and analyze select gatherings and celebrations to identify how gender, race, stereotypes and images were configurated and mobilized in narratives that structured Brazilian identity, ethnic groups and social boundaries.

actices, discourses and aesthetics I examined gained reality in a specific junction of time and space (Gallo, 2009). They exist temporarily in shows, rodas de capoeira, rituals, dances, celebrations and theater plays, among others. I defined these cultural scenes as my unit of research. Although these performances are restricted in time, the effects of their influence are spread throughout time. Therefore, I studied these performances in terms of a) their importance in relation to other events; b) their trajectory throughout time (how they contribute to a selective collective memory of Brazilian migrants and reinforce or challenge established ideas); c) if they were conceived of (or tailored) for a Brazilian or American audience; d) what regional or historical aspects of Brazil they were based on; and e) the individuals or groups organizing, selecting and promoting these cultural activities.

10 The connections between cultural scenes and the configuration of Brazilian identities are formed through the understanding of ethnic identity as narrative(s) (Cornell, 2000; Jiménez, 2010). These narratives are defined as:

«[...]collective life stories created through the selection, plotting, and interpretation of certain events that are seen as common to the experiences of a group [...] that may be big or small, episodic or quotidian, historical or ongoing [...] they are interpreted, imbued with significance, and subject to claims about the extent to which they [...] define the group. » (Jimenez, 2010, pp. 23-24)

11 Therefore, it is possible to characterize ethnic identities as event-centered (Cornell, 2000), as bringing together the past and the present, mixing reality and fiction. The events are not only intrinsically important; they also inform the claims are made around and because of them, as well as the power relations in which these claims are embedded.

The experience of arriving to Los Angeles and starting to observe and collect Brazilian cultural scenes required familiarizing myself with social networks, navigating between spaces (dance studios, gyms, theaters), getting to know people involved in these activities and gaining access to other spaces. In the first few weeks, I decided to observe and participate in all the events I could, yet uncertainty about the significance of each event made me feel like I was "hopping around" (Hage, 2005). Therefore, the indecision I felt about how to choose my observations grew. Considering the richness and vastness 
of the cultural market in Los Angeles, in addition to the size of the city itself, I started literally mapping my observations, which gave me a sense, over time and after getting to know the city, of the importance of each place. Following this discussion about the social construction of space and the interconnectivity of sites, a graphic expression could help visualize the variation of locations.

Map $n^{\circ} 1$ : Geographical location of some events in th County of Los Angeles

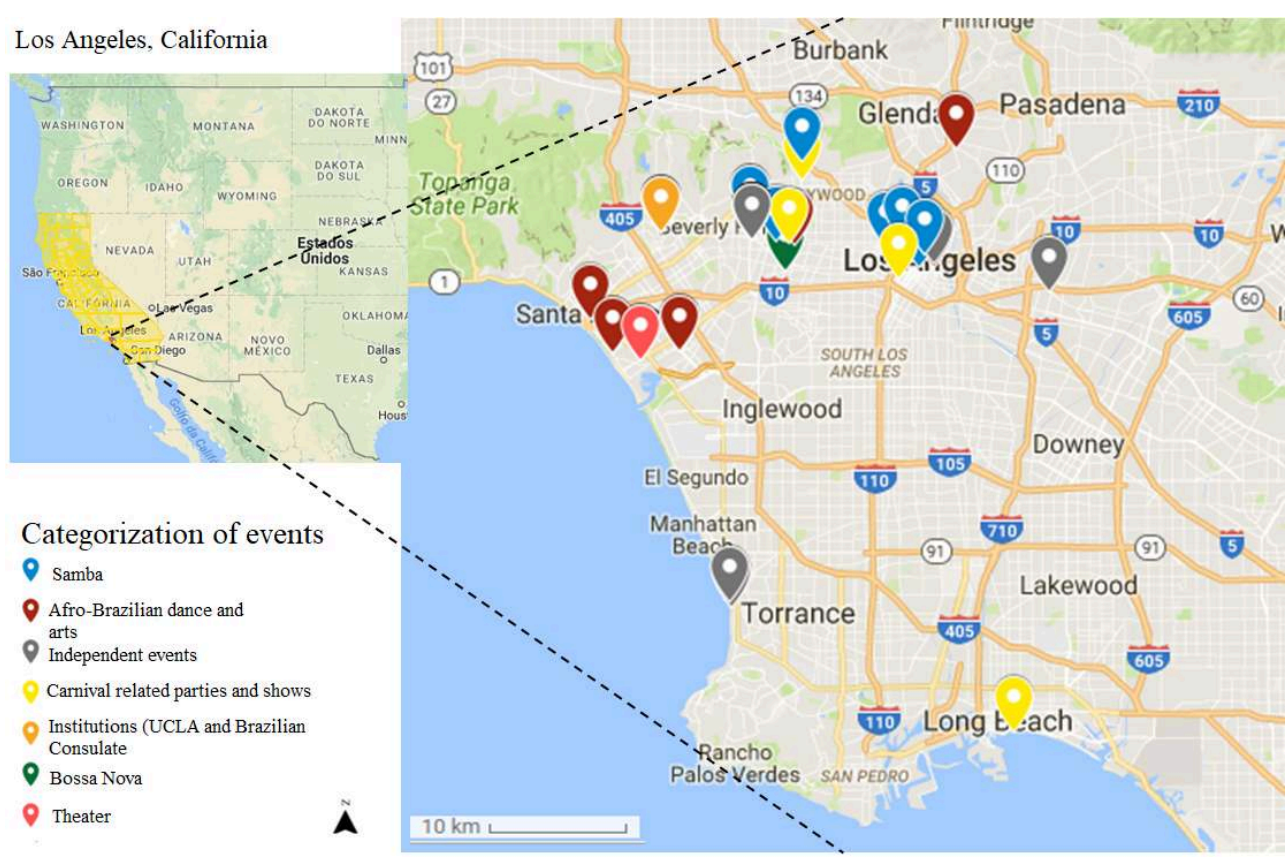

Source : Alloatti, 2017.

13 This visualization informed later interviews, participations, volunteer work and the general learning process with those subjects that I characterized as paraethnographers. Yet, as frequently happens, significant worries emerged throughout the first weeks of fieldwork.

In my case, these worries were mostly tied to a traditional perspective of ethnography. I had doubts about how to define my fieldsite(s). I could not decide if I should refer to the city of Los Angeles as my locale, as the big urban space where the dwelling and observation is conducted (Clifford, 1997), or if each cultural scene could be treated as a site, opening the door to a multi-sited perspective. The former would define each event as an opportunity to observe migrants' cultural life in Los Angeles as connected by a broad notion of Brazilian culture. Yet somehow, this way of thinking gave me the impression of a holistic assumption, the idea that I would be researching a part of something bigger that exists and is "out there" (Coleman and Hellerman, 2011; Candea, 2009). This could diminish the importance of the fragmentary character of the phenomena I was analyzing and would risk missing much of the specificity. In other words, multi-sitedness gave a higher status not only to the (negotiated and imagined) social spaces in question, but also to the spatialized cultural difference. Questioning and deconstructing the field as a given place of bounded culture permitted me to work through the partiality of social life. Furthermore, it allowed me to see how spatial practices and embodied sense-making practices could turn a parade into a ritual in a highly touristic place (Clifford, 1997; Gupta and Ferguson, 1997; 2011). 

decisions. Through time and a cumulative process, I developed a criterion to select the events I wanted to observe (Horst, 2009; Gallo, 2009). This process of bounding the fieldsites gave special attention to their specificity, their fluidity and how they spread through time (Candea, 2009). Because each site is the junction of time and place, this also incorporated the relevance of «different locations [in] the importance of the embedding of social action " (Crang, 2011, p. 36). In other words, I would examine the symbolic and economic effects of occupying spaces such as the Hollywood Bowl, or Venice Beach, but also how practices imbued with (religious and/or sacred) meaning transform the space.

During the year I spent in Los Angeles, I conducted participant-observation of forty-one events that I registered with notes, recorded (when possible) photos and videos and collected the material used for event promotion (pamphlets, images on Facebook). I divided the events in categories that I (re)defined throughout the fieldwork. However, overlapping was common-for instance, bossa nova shows could be also samba shows or independent events. The map I created does not show all my observations, since several took place at the same locale (the Brazilian Consulate, UCLA, studios and gyms). Although I lose some representation because of this, the map gives an idea of which places are coveted and problematizes who has access to them.

The mapping exercise allowed passage from the city as a realm of analysis for social networks. I realized I was following some people, who had become prominent due to their overrepresentation, who were working in the same activity but with different collaborators and in diverse settings. For example, Nina had her own company, yet I saw her in the organization of another company and teaching with other people in different studios. Therefore, I started to see the connections and the circulation of people among sites that initially seemed disconnected. This further informed my selection when I wanted to see different activities by the same people, or wanted to observe something completely unrelated to the subjects I already met. My methodological approach became strengthened as I progressively selected sites and people as part of a reflexive cumulative process. I started expanding the bounding of sites and re-shifting locations as I considered possible cross-fertilization and changes in the social hierarchy of sites and subjects.

Although my data was gathered within and across different sites in the city of Los Angeles, interpretive analysis of meanings, practices, languages, references and translocal connections was conducted at a transnational U.S. / Brazil level. While the results that I describe in this paper are indexical to the social configurations of Los Angeles, identifying the links with local spaces in Brazil required building a connection with several spaces and events in the history of Brazil (some of the evocations, references and cultural innovations being offered in Los Angeles were connected to past events in Brazil, particularly the history of slavery and the building of the nation state). Before moving to Los Angeles, during my stay there and while writing my dissertation back in Brazil, I consulted colleagues, empirical research, historical analysis and cultural studies transiting between topics (Afro-Brazilian cultural heritage, capoeira, samba, etc.) and geographical references that emerged in my fieldwork (the city of Salvador, Reconcavo Baiano, neighborhoods in Rio de Janeiro and the Northeast region, among others). My goal was to identify the singularity of what 
was taking place in Los Angeles through historical, transnational and translocal connections.

\section{Between theory and practice: two challenges of a multi-sited research}

I discuss here two important aspects of my investigation that emerged in the dialogue between a traditional way of defining ethnography and a multi-sited approach. The first one was already mentioned: the connection between the locale, where events took place, and the definition of site. I was frequently concerned about reifying localness and « losing a sense of flow and movement when we spatialized the field» (Crang, 2011, p. 38). In cases such as LACMA (Los Angeles County Museum of Art) or Hollywood Boulevard-famous spaces that grant high visibility-I was afraid the location would become more important in my analysis than the actual performance I was observing. In other words, I was concern about giving primacy to the place itself. To avoid this, I found it helpful to continuously question the process of negotiating the space and the mechanisms that gave access to only certain groups and individuals.

I selected here an excerpt from my first fieldwork notebook on a Brazilian music show for kids during the summer at the Hollywood Bowl. As part of the cumulative process I mentioned earlier, I started going back ${ }^{3}$ to my notes and adding thoughts inspired mostly by new observations. In this case, I incorporated questions to reflect on my own experience with accessing this scene (time, public transportation).

About the importance of places, in the case of the Hollywood Bowl: How did they get access? How many events took place here? Consider those that will be presented in the future. Who got access before? (questions added in October 2015). About the music show: I took only one bus $\left(n^{\circ} 105\right)$ and it took me around an hour and a half to get to the last bus stop on Hollywood Boulevard. From there I walked 20 minutes. To remember: when asking for directions, several people told me to go by car. Consider the importance of the place by itself, but also the location within the urban space of the city. Certain points in Los Angeles are difficult to access by public transportation because of routes and schedules, in other places like Downtown L.A., parking can be expensive. Related to private parties or dinners [for example the bossa nova dinner in May], which were supposed to be opened to everybody, yet since it was in private residencies, some people did not know how to get there, the public was exclusive (limited to 50 people). (Fieldwork notebook $\mathrm{n}^{\circ} 1$, The Summer sound world music for Kids. 8th August 2015, Hollywood Bowl. With added notes)

21 This "going back" to my notes was also motivated by interviews and conversations. I selected a part of Nina's interview in which she explained how being part of the Los Angeles-Salvador Sister Cities Committee opens new spaces for those who are part of it. Los Angeles has cultural projects with several cities around the world. Nina and Sarah constitute the committee that regulates cooperation between Los Angeles and Salvador, Bahia. Their projects are mostly dedicated to cultural activities and heritage. I got basic information about these committees at their website ${ }^{4}$ and a Facebook page where it is possible to see the schedule for the priestess's future visits, photos and some information related to Candomblé. Nina's ample access to important places and spaces 
not only occurs in the city of Los Angeles, but is transnational, since it also opens doors in Brazil.

Nina: The sister city for L.A. with Salvador was inactive for several years. So because it is not a nonprofit, Sarah [her friend] requested because she wanted to dance in a sister city, with her company. We went to City Hall and they were like 'Oh please, yes....' It has been great. We got a lot of things through it, like this famous guy from Brazil came and he sang at City Hall, introduced to beautiful talks we try to sponsor.

Magali: So through this sisterhood you are able to get to more spaces?

Nina: Not that much, sometimes we get to use city hall and when we go to Salvador we get to talk to some people, officials, knowing culturally what is going on there. We are much more involved. Several of the sister cities are more material. We decided only to focus on art and culture. And it has become art. (Nina, January 11, 2016)

There are different ways in which the junction between the place and what is being performed configures a site in terms of the social construction of space. I needed to consider what I was observing, who gets to perform in this particular space and who is a part of the audience. The urban characteristics of a city such as Los Angeles have considerable impact on the economic and symbolic effect of occupying a specific locale and on the hierarchy of cultural activities. This is a particularly important example of Nina's empowerment through the Sister Cities Committee, which grants her international access a) to enter important locales in Los Angeles, b) to offer these spaces to invited Brazilian artists and c) to access specific places in Brazil. In an informal conversation, Nina explained to me that "anyone can be part of this committee as long as they are American citizens," which would exclude most of the people I met and interviewed during my fieldwork. Consequently, Americans (and only a few Brazilians who became American citizens) can be part of this configuration.

The second concern I had was also related to the junction of time and place. Because my units of research had short duration, I was worried about achieving the necessary depth for an ethnographic study. In a more traditional understanding, the assumption of shared experience as the base for comprehending social life makes the dwelling a crucial factor. It is the combination of a significant amount of time in a specific space that gives value to participant-observation as the main technique for understanding. However, as Falzon (2009) explains, the potentiality (and challenge) of a multi-sited approach lies in questioning the traditional process of production of depth and thickness.

After a few months of observations, interviews and the exercise of "going back" to my own notes, I realized most cultural activities were organized in a multi-sited fashion. It was common for the cultural producers and artists to prepare schedules, workshops, lessons and shows depending on other events occurring in the same week or month, or sometimes even at the same time. Or, in the case of residencies and religious festivals, they would plan based on those that occurred in previous years. Some international guests would participate in different spectacles during the same day. Costumes and musicians circulated throughout the city in the same night. Disputes grew and were 
solved during February, the month of carnival and the proliferation of official carnival parties. Moreover, some events were only possible due to the subject's transnational ties, through which goods, people, ideas and emotions circulate. In some cases, experiences were shared among students and teacher, playing a significant role in establishing links between sites and events. Therefore, I identified international, transnational and local ties that were built through time and activated in specific situations.

Strong memories and shared experiences were crucial in the case of an Afro-Brazilian dance company that has been organizing summer trips to the state of Bahia (Brazil) for the past fourteen years. These trips are sold as a "cultural immersion experience" and advertised as "learning from the source," since Bahia is considered the place of origin for Candomble and the "survival of Africa in Brazil" (Pinho, 2002; Sansi, 2007). During these trips, students and dance teachers visit sacred places, participate in rituals, meet mães and pais de santos and learn dances. During most of the lessons and activities (such as the ritual at Abbot Kinney), these trips were referred to frequently through the expression of memory and feelings. Moreover, during their visits to Brazil, the women in Nina's group bought special clothing and jewelry, some made by the mãe de santo, and used them during the parade. Those who buy these clothes and participate in the trips are strongly involved in these activities for a long time and define themselves as part of a community. Thus, travelling and owning the clothes and jewelry are proof of membership and knowledge.

Therefore, these activities and experiences, as well as the bonds created through them, needed to be analyzed in a multi-sited perspective (Horst, 2009). The parade at Abbot Kinney became a ritual because of the presence of the Brazilian priestess, but also because of the clothing and jewelry the women wore and the dance movements they learned with Nina during the lessons and trips to Bahia. I selected an excerpt of an interview with Dona (a young teacher of Afro-Brazilian dance) in which she discusses her class by referring to movements, music and religion, but mostly to "ways of feelin'."

Dona: They play for ceremony as well, for Ifã, other ceremonies and things like that. When people come to my class, the drumming makes them, they are speaking to spirits, so even though it is just a class, people can feel that [...] like, that is a song that you would sing if you want an Orixá to come to the space. A lot of time, it is not related to the movement but the song, sometimes I can feel it, I feel like "ok, now I need to calm down". I will get lightheaded or people would be like "ufff....ufff". There was this time when we did the festival one time, a girl felt like, she got, she received her Orixá; she was suddenly out of it. We helped her, with one of the drummers. (Dona, February 9, 2016)

As Boccagni (2014) explains, the risk of a shallow field experience is related to emotions and feelings (in which we are as involved as those we perceive), factors which played a significant part in my research. Events and occurrences were remembered and narrated by participants during lessons or shows in an extremely emotional manner, not only because these occurrences were inserted and interpreted in a religious system, but because of the way the subjects are expected to feel during these dance lessons and encounters (Halloy, 2016). The interview excerpts show the need for a thinner and/or thicker analysis regarding the events, which guided me in the selection of sites and 
occurrences. Understanding the feelings of teachers and students became a form of orientation when choosing scenes that required deeper analysis using different techniques, such as interviews, "going back" to my notes and self-reflection on my own impressions.

\section{Para-ethnographers as partners in the research: working side by side}

Considering the complexity of the experiences I mentioned, it was clear that to fully understand the entanglement of sites, activities and people, I needed help. During my fieldwork, I met forty-five prominent individuals in the field of Brazilian culture in Los Angeles, people with whom I took lessons, participated in events and conducted indepth interviews. While I concentrated on developing a multi-sited research project, I was also learning about Brazilian culture in a more general way. Although I have lived and studied in Brazil for years, several aspects related to Afro-Brazilian cultural heritage, music history and regionalisms were unknown to me. Therefore, I needed to make clear that my relationship with these subjects was different from a traditional ethnographic perspective-I was learning from and with them. Feeling the need to include and describe these subjects beyond the category of informants, I decided to incorporate the notion of para-ethnographers as "nodes in distributed systems, perceived as knowledge-makers and not merely holders " (Coleman and Hellermann, 2011, p. 5).

The idea of working and learning in partnership with these agents challenges the Malinowskian image of the informant, eliciting the notion of social reality as a system of distributed knowledge (Marcus, 2011, note 2). Para-ethnographers are individuals who are inserted in this system and who must be characterized by their «own specificity, entangled in a particular set of forces [and by their] active sense making, the knowledge making» (Fortune in Marcus, 2011, p. 25). According to Holmes and Marcus (2005), they exist in social realms of which they have expert knowledge derived from their positions. Therefore, the traditional notion of informant is no longer advantageous. These subjects deal with different level of data, information and other subjects within a specific field in which they have a role in producing, mediating and distributing representations (Holmes and Marcus, 2005, pp. 238-240). This perspective toward para-ethnographers allowed me to (re)define my working relationship with people I met. I decided to explore this connection by using new ways of learning. In several occasions, I took my observation notes to the interviews and asked them about what I saw and felt. I shared my impressions, ideas and academic readings with them, a strategy, which took our dialogues to new levels.

More importantly, the category of para-ethnographers complexified these subject's positions as knowledge makers; I perceived them as translators and interpreters in the process of teaching and performing cultural activities. In the case of Afro-Brazilian dances, this became evident when they invited professors and priestesses from Brazil. Because the guests did not speak English, my interviewees would translate for them while also explaining the class's cultural content and, more importantly, the feelings that would emerge and guide the learning process. In the case of Afro-Brazilian dances, I understood that their expert knowledge derives from, and is reinforced by, a) a professional education, b) an international trajectory-their learning process "at the 
original sources" (Brazil or Salvador)-and c) the fact that they have been initiated in the religion of Candomblé. Nina and Sarah became cultural mediators who create, select and reinforce narratives about (true and authentic) Afro-Brazilian history and cultural heritage in Los Angeles (Hobsbawn, 1983; Cornell, 2000). These subjects' daily life experiences, the "fugitive social facts" (see excerpt from Dona's interview), are part of the process of knowledge production with a high symbolic efficiency, determining and reproducing their position within a hierarchy of experts.

31 A last consideration on this point refers to my proximity to these subjects as a precondition of characterizing them as para-ethnographers. As mentioned by Carling, Erdal and Ezzati (2014), in migration studies the insider-outsider distinction has been established and reinforced by the ethno-national characteristics of the group being studied and the researcher's characteristics and belonging. These authors call our attention to the changeable conditions of insider-outsider, which vary according to specific (micro-social) situations, forms of interactions and effects of specific markers that define the researcher's position and the social categories that they use. In my case, language skills and cultural competence were the factors that contributed to building proximity with para-ethnographers. Proximity boosted trust regarding negative aspects of Brazil, experiences of racial and gender discrimination in the U.S. and disloyal forms of competition among artists in the city.

When defining my relationship as a researcher and an apprentice of these subjects, I adapt Carling, Erdal and Ezzati's classification of third position (pp. 50-52). While I was an explicit third party (neither Brazilian nor American), proximity and trust were mostly based on being an honorary insider due to my commitment to studying Brazilian migration as well as my language skills and cultural competence. As Matejskova (2014) put it, a relationship with the para-ethnographers and interviewees emerged and was negotiated and updated in different times and spaces; thus, proximity was a deeply situational process (p. 17). Since I was engaged in learning with and from the paraethnographers, I underwent a process of becoming part of what they defined as communities by being continuously present, incorporating attitudes and behaviors and showing myself to be open to experiencing the activities in the way they instructed. The "momentary spaces in which closeness was made" (Matejskova, 2014, p. 20) allowed for further interviews and dialogues. Therefore, my learning process from and with para-ethnographers was based on their specific knowledge about cultural activities (history, music, religion), on my role as a student, and on our shared moments and events, all of which were always framed in a situational fashion.

\section{When people are the links: the para-ethnographers as connection between sites}

33 In my constant effort to identify links between sites and make them intelligible, I started paying attention to specific social relations between the subjects and cultural scenes in a cross-fertilization fashion (Gallo, 2009). Emphasizing the social relationship between the people was a way of re-creating the history and context of cultural activities. Furthermore, different practices, discourses and uses of some things (such as the clothing) made sense because of relationships between people (Ferguson, 2011, p. 198). Thus, I realized that in many occasions, the para-ethnographers themselves were the links connecting the sites. In other words, if sites are a « simultaneous reference to 
two (or more) significant locales being physically remote, biographically displaced from one another, " then we must pay special attention to how they are "still potentially connected by migrants' transnational ties » (Boccagni, 2010, p. 4). Moreover, if sites are defined relationally and created in their connection with others, then these relations, the links, must be conveyed in the analysis (Crang, 2011). I explored how the (transnational and/or local) ties were established and maintained, keeping in mind that local realities are, or can be, "produced elsewhere through dispersed relations and agencies » (Marcus, 2011, p. 20).

All the cultural scenes I observed and took part in deployed significant efforts to evoke a specific Brazilian cultural context through a language filled with motions, descriptions and foreign words. During samba and carnival shows, artists and performers produced discourses that sought to explain and teach the audience "how you feel" when in Brazil, describing the heat, the sweating and the cheerfulness of the Brazilian people. In the case of bossa nova spectacles, the emphasis was put on detailed geographical description of Rio de Janeiro, Copacabana beach, the sea breeze and the bohemian "way of life." In the case of Afro-Brazilian dances and arts, the sites were defined and connected through two intertwined elements: a) the limits between sacred and profane (what distinguishes a dance from a ritual, what can be performed in public) and b) the connection between the people.

Magali: I saw so many artists at the play, do they work with you?

João: It is a combination. For example, Ramona, we used to be in a group together, even before we came to the States we used to work together in Salvador. I consider her my sister, we work together all the time. She is family, definitely family. And there are people like Mestre Roque who came to support and Mestre Zoe from Italy, we invited him. So, we are connecting people you know, we trained in Bahia, now he lives in Italy and other men are in Australia. We have this world connection, we are here locally but we are connected globally. Which is very interesting, through capoeira, through art and music we have a huge community [João, December 22, 2015).

Sarah: We can learn from and certainly with Dona Lala [priestess] as a cultural consultant and our spiritual consultant. We learn more about how we can take this sacred material and popularized transforming it into stage presentation [...] when you think about it this is music that was sung way before 1500 when the African slaves were brought to Brazil. And this music is alive in a lot of parts of Brazil, it is certainly alive here in Los Angeles. Dona Lala thinks that Los Angeles has become a key city in the African Diaspora; [she] has been with us, back and forth since 2005. And it's really incredible to learn the secret songs-which songs we can sing, for example, on the stage and which songs are more sacred and are kept for ceremony. (Sarah and Dona Lala interview at a radio show. May 22, 2015).

Magali: What is sacred...that you cannot do?

Sarah: We can wear contas [jewelry used in Candomblé]. Certain songs for example, because they will induce trance and some of the songs and the energy from the meanings of the songs are... it is not for public consumption. There are some dances too, because of the dances, the song and the dance go hand by hand, 
we are not allowed to do. And this is a constant dialogue for us between our elder of the Candomblé. Constantly, working with Dona Lala for example, working with Titia, what is about Orixás costume. We don't dance that much actually with the Orixás particularly, but elements in the ceremonial costumes perhaps should not be worn in a public presentation. It is a constant dialogue [....] Dona Lala tells us how to, Titia comes to make the costumes, but Dona Lala tells us what we can and cannot do; as I told you, it is constant consultation. I am on the phone with them constantly. (Sarah, January 16, 2016) as family-they share their homes and have been close for several years. The religion mediates and shapes their connection. In Candomblé, the name for priestesses is the Portuguese word for mother (mãe de santos) and for priest is the word for father (pãe de santos). Sarah frequently refers to the priestesses as mothers, her Brazilian mothers. Since the priestesses are the ones establishing the threshold between sacred and profane, what can be performed, sang and worn in public and what cannot, they have constant communication in the form of consultancy. When in Los Angeles, these women participate in shows, festival, rituals and lessons. Their physical presence can be determinant, as in the case of the Abbot Kinney Festival, transforming the parade into a ritual. They also bring the fabric for the costumes from Salvador and design the clothes and jewelry for the dance companies. When they are not physically present, the contact is done "constantly on the phone," assuring-through the advisory-the legitimacy of Sarah and Nina's work in the field of Afro-Brazilian art.

37 I believe the category of para-ethnographers provided an additional advantage. As I showed earlier, it was common to hear that Brazil is the original place of their dance, music and traditions. Therefore, Brazilians usually have an ethnic advantage in the cultural market. Yet Americans who studied, lived or learned in this country manage to balance the difference and sometimes conquer some niches within the market. Consequently, several strategies of transnational mobility are deployed to travel to Brazil and "bring back" symbolic capital, in the form of objects, music instruments, feathers and crowns for carnival parties. Some people bring back "proof" of participation, of "being there"-a tanned body, new ways of dancing, photos, etc. It is a particular form of knowledge to effectively "bring back" symbolic capital and mobilize it through social media and networks to transform it into an ethnic advantage in the cultural market.

The para-ethnographers become the links; they embody the connection with Brazil and/or Brazilian culture by travelling and creating flows of goods, images and feelings. 
They possess a specific knowledge beyond the locale (Salvador, Rio de Janeiro, a samba school or Los Angeles). It is about the movement of people and things. It is expertise about travelling and how to move, to navigate different economic, cultural and social contexts (Clifford 1997). They have the ability to choose what they "bring back" to the U.S. and how they will commodify it as part of their cultural offer efficiently enough to maintain or gain new space in the cultural market.

\section{Conclusion}

\section{西} changeable. At first impression, it might seem that the movement is one of "importing" Brazilian culture to the U.S. through music, musicians, artists, capoeira, religion and rituals while trying to maintain it as unaltered as possible with respect to authenticity. Yet by identifying and understanding the links and bridges between sites, as imagined constructions distant geographically and temporally, the importance of social agency and hierarchy among those involved in these cultural activities emerges as a crucial factor. What circulates transnationally is (re)created and (re)signified by this movement. Moreover, some activities are only commodified in the context of migration, through a process that articulates the selection and creation of traditions and narratives for those who seek to establish themselves as authorized voices of what is Brazilian and what is not. For some artists based in Brazil, performing in Los Angeles and returning to Brazil is a process of consolidating their trajectory as professionals who transit through an international cultural hub. Therefore, the challenge for me was to identify the circulation of culture, to comprehend how certain individuals are the links between sites and how their position is reinforced during the knowledge-making process.

41 As I mentioned, the main aspect that worried me was the connection between observation and comprehension proposed in a traditional definition of ethnographic work. Specifically, I was concerned about the assumption that a shared experience (through time and dwelling) is the key for the researcher to understand and comprehend the social life they are observing. As part of this experience, I believe the methodological caution of being sincere (Boccagni, 2014) needs to be fully embraced. I realized that to comprehend observations and participations was not enough, and that in-depth interviews would only contribute partially. I needed to rebuild and redefine my relationships with the subjects I met, to qualify their knowledge in order to improve mine. The para-ethnographers needed to become more than a category or a description. This is a way of conceiving new forms of knowledge, of being able to 
dialogue and learn from it, to incorporate it while working side-by-side with individuals or groups.

If ethnography "is about how one culture is portrayed in terms of another [then] it rests on the peculiar practice of representing the social reality of others through the analysis of one's own experience in the world of these others" (Van Maanen, 2011, p xiii). My own experience was created, guided and informed by my knowledge of paraethnographers. When conducting observations, I learned from them in the same way other students learn about the history of samba, Orixá traditions or Brazilian folklore. Following Van Maanen, I believe a study of culture should focus on a particular group of people, in specific places and times, understanding that culture is contested, bounded, dislocated, fragmentary and episodic. Therefore, how could I attempt to understand and explain the Brazilian cultural scenes in Los Angeles without the help and knowledge of para-ethnographers?

Marcus says «there is something about the way traditional units or objects of study present themselves nowadays » (2011, p. 17) that makes us question the Malinowskian model of ethnography. Maybe some things have changed too much, or maybe we got them wrong from the beginning. Beyond a discussion of holism and realism (the objects present themselves in a new way, therefore our methodology must change), it is imperative to be sincere and to ponder our limitations in the process of researching. Our restrictions might be related to time or manpower as well as theory or methodological expertise. I believe the only way we can address and overcome these limitations is by prioritizing our questions instead of what we already know.

\section{BIBLIOGRAPHY}

Boccagni, Paolo (2014) From the Multi-Sited to the in-between: Ethnography as a Way of Delving into Migrants' Transnational Relationships, International Journal of Social Research Methodology, vol. $19, \mathrm{n}^{\circ} 1$, pp. 1-16.

Boccagni, Paolo (2010) Exploring Migrants' Affective Ties at a Distance: Is 'Multi-Sited' ethnography Enough?, Working Papers, Center on Migration, Citizenship and Development, $\mathrm{n}^{\circ} 72$, pp. 1-16.

Candea, Matei (2009) Chapter 1. Arbitrary locations: in defence of the bounded field-site, in Falzon, M.-A. (ed.) Multi-Sited Ethnography. Theory, Praxis and Locality in Comtemporary Research, London, Routledge, pp. 25-45.

Carling, J. ; Erdal, M.-B. ; Ezzati, R. (2014) Beyond the insider-outsider divide in migration research, Migration Studies, vol. 2, n 1, pp. 36-54.

Clifford, James (1997) Routes: travel and translation in the late twentieth century, Cambridge ; London, Harvard University Press, $408 \mathrm{p}$.

Clifford, James (2011) A experiência etnográfica. Etnografia e literatura no Século XX, Rio de Janeiro, Editora UFRJ, 319 p. 
Coimbra de Sá, Natalia (2011) Espetáculos Culturais Brasileiros Na Cidade de Nova York: Múltiplas Perspectivas, Salvador, Bahia. Universidade Federal da Bahia. 348 p. (Th. Doct: Programa Multidisciplinar de Pós-Graduação em Cultura e sociedade. Salvador: 2011).

Crang, Michale (2011) Part A Introduction, in Coleman, S. ; Hellermann, P. (eds) Multi-Sited Ethnography. Problems and Possibilities in the Translocation of Research Methods, London, Routledge, pp 35-40.

Coleman, Simon ; Hellermann, Pauline (2011) Introduction. Queries, collaborations, Calibrations, in Coleman, S. ; Hellermann, P. (eds) Multi-Sited Ethnography. Problems and Possibilities in the Translocation of Research Methods, London, Routledge, pp. 1-15.

Cornell, Stephen (2000) That's the story of our life, in Spickard, P. ; Burroughs, J. (eds.) We are a people. Narrative and multiplicity in constructing ethnic identity, Philadelphia, Temple University Press, pp. 41-53.

Falzon, Mark-Anthony (2009) Introduction. Multi-sited ethnography: theory, praxis and locality in contemporary research, in Falzon, M.-A. (ed.) Multi-Sited Ethnography. Theory, Praxis and Locality in Comtemporary Research, London, Routledge, pp. 1-15.

Ferguson, James (2011) Novelty and method. Reflections on Global fieldwork, in Coleman, S. ; Hellermann, P. (eds.) Multi-Sited Ethnography. Problems and Possibilities in the Translocation of Research Methods, London, Routledge, pp. 194-207.

Frangella, Simone (2013) Afro-Brazilian Culture in London: Images and Discourses in Transnational Movements, Portuguese Studies, vol. 29, n¹, pp. 78-93.

Gallo, Ester (2009) Chapter 4. In the right place at the right time? Reflections on multi-sited ethnography in the age of migration, in Falzon, M.-A. (ed.) Multi-Sited Ethnography. Theory, Praxis and Locality in Comtemporary Research, London, Routledge, pp. 87-102.

Gupta, Akhil ; Ferguson, James (eds.) (1997) Anthropological Locations. Boundaries and Grounds of a Field Science, Berkeley, University of California Press, 275 p.

Gupta, Akhil ; Ferguson, James (2001) Culture, Power, Place. Explorations in Critical Anthropology, Durham ; London, Duke University Press, 361 p.

Hage, Ghassan (2005) A Not so Multi-Sited Ethnography of a Not so Imagined Community, Anthropological Theory, vol. 5, $\mathrm{n}^{\circ} 4$, pp. 463-475.

Halloy, Arnaud (2016) Full Participation And Ethnographic Reflexivity. An Afro-Brazilian Case Study, Journal for the Study of Religious Experience, vol. 2, n¹, pp. 7-24.

Hannerz, Ulf (2003) Being There ... and There ... and There!, Ethnography, vol. 4, n² 2, pp. 201-216.

Hobsbawm, Eric (1983) introduction: inventing traditions. Hobsbawm, in Eric; Ranger, Terence, (eds.) The invention of tradition, Cambridge, Cambridge University Press, pp. 1- 14.

Holmes, Douglas ; Marcus, George (2005) Culture of expertise and the management of globalization: toward the re-functioning of ethnography, in Ong, A. ; Collier, S. J. (eds.) Global Assemblages. Technology, Politics and Ethics as Anthropological Problems, London, Blackwell, pp. 235-254.

Horst, Cindy (2009) Chapter 6. Expanding sites: the question of 'depth' explored, in Falzon, M.-A. (ed.) Multi-Sited Ethnography. Theory, Praxis and Locality in Comtemporary Research, London, Routledge, pp 119-133.

Jiménez, Tomás (2010) Replenished Ethnicity. Mexican Americans, Immigration and Identity, Los Angeles, University of California Press, 347 p. 
Maanen, John van (2011) Tales of the Field. On Sriting Ethnography, Chicago, The University of Chicago Press, 216 p.

Matejskova, Tatiana (2014) Deep situationality: Interstitial spaces and limits of identity in ethnographies of politics of immigrant integration, Migration Studies, vol. 2, n¹, pp. 16-35.

Marcus, George (1998) Ethnography through Thick and Thin. Katalog BPS, Princeton, Princeton University Press, 288 p.

Marcus, George (2011) Multi-sited ethnography. Five or six things I know about it now, in Coleman, S. ; Hellermann, P. (eds.) Multi-Sited Ethnography. Problems and Possibilities in the Translocation of Research Methods, London, Routledge, pp. 16-32.

Pinho, Osmundo de Araujo (2002) Deusas do Ébano: a construção da beleza negra como uma categoria nativa da reafricanização em Salvador. XXVI Encontro Anual da ANPOCS. Caxambu, Brazil, pp 1-23.

Prandi, Reginaldo (2004) O Brasil Com Axé: Candomblé E Umbanda No Mercado Religioso, Estudos Avançados, $\mathrm{n}^{\circ} 18$, vol. 52, pp. 223-238.

Ribeiro, Gustavo (1999) O que faz o Brasil, Brazil: jogos identitários em São Francisco, in Reis, R. ; Sales, T. (dir.) Cenas do Brasil Migrante, São Paulo, Boitempo, pp. 45-87.

Sansi, Roger (2007) Fetishes and Monuments. Afro-Brazilian Art and Culture in the Twentieth Century, New York; Oxford, Berghahn Books, 216 p.

Sterling, Cheryl (2012) African Roots, Brazilian Rites. Cultural and National Identity in Brazil, New York, Palgrave Macmillan, $260 \mathrm{p}$.

\section{NOTES}

1. As agreed upon with the interviewees, all names have been changed.

2. All translations are by the author

3. I use the expression "going back" as a continuous exercise of (re) reading my notes, organizing them in an activity log and using pictures and photos in the process of analysis. I also added comments I collected from the Facebook groups or heard from people in the following days and weeks. New notes were added in italic so I could identify them in the following readings and in my conversations with the para-ethnographers.

4. http://sistercitiesofla.org/

\section{ABSTRACTS}

In the last two decades, there has been considerable debate around the emergence of multi-sited ethnography. Most critics of multi-sited ethnography have focused on its ontological premise, risks of holism and, most importantly, methodological applications (Hage, 2005). These topics have been further developed by adherents to a multi-sited approach, mostly through empirical examples (Falzon, 2009; Colermand and Hellerman, 2011). In this paper, I engage in this debate by problematizing my research on Brazilian culture in Los Angeles, paying special attention to the 
limitations I recognize in a more traditional definition of ethnography. The aspect of multi-sited ethnography that seems especially questionable is the assumption that a shared experience between researcher and informants would produce comprehension of social life. This postulation gives a superior status to the dwelling and privileges observation as the primary means of analyzing and comprehending. I reflect on the challenges I faced in doing research and how I was able to overcome previous assumptions by incorporating strategies from a multi-sited approach. Specifically, I discuss the debate around ideas around conceptualizing space, defining sites and categorizing the roles of para-ethnographers. I conclude with a short reflection on the importance of acknowledging the problems we face while conducting research and how these problems can be a guide to overcoming methodological and practical limitations.

\section{INDEX}

Mots-clés: méthodologie, ethnographie, relations avec le pays d'origine, intégration sociale, culture d'origine, Brésilien

Geographical index: États-Unis

\section{AUTHOR}

\section{MAGALI N. ALLOATTI}

Researcher at the State Observatory for Migrations, State University of Santa Catarina, Brazil magalialloatti@gmail.com 